\title{
Effects of various inhibitors including carboxin on Botrytis cinerea mitochondria isolated from mycelium
}

\author{
R Fritz *, C Lanen, V Drouhot \\ INRA, Laboratoire de Phytopharmacie, 78000 Versailles, France
}

(Received 30 November 1992; accepted 21 December 1992)

\begin{abstract}
Summary - Due to the development of resistant srains, the practical control of Botrytis cinerea remains a problem. Little is known about its respiratory chain and this paper describes the preparation and the properties of $B$ cinerea mitochondria with the aim of testing new antifungal compounds. NADH, succinate and $\alpha$-ketoglutarate as substrates provided good oxygen consumption. Respiratory control ratios were high and showed that electron transport was well coupled to oxidative phosphorylation. The phosphorylation efficiencies (ADP/O) obtained with all 3 substrates were compatible with theoretical values. The addition of cytochrome $c$ did not greatly enhance the oxygen consumption due to ascorbate: the quality of the outer mitochondrial membrane was good enough to prevent externally added cytochrome $c$ from interacting easily with the respiratory chain. These observations indicate that the mitochondria isolated sustain a high level of structural and functional integrity. This study showed also that they were devoid of the alternative pathway resistant to antimycin $A$ and cyanide, but that they exhibited a rotenone-insensitive respiratory route. The action and the effective doses of oligomycin, carbonylcyanide $m$-chlorophenylhydrazone (CCCP) and carboxyatractyloside on $B$ cinerea mitochondria were similar to those observed with plant mitochondria. At $10 \mu \mathrm{M}$, carboxin completely inhibited succinate oxidation in mitochondria from $B$ cinerea but failed to have any effect on NADH and $\alpha$ ketoglutarate oxidation. This toxicity level was comparable to that reported by other authors with members of the fungal class Basidiomycetes.
\end{abstract}

respiration inhibitors / rotenone insensitive route / carboxin / alternative pathway / B cinerea

Résumé - Effets d'inhibiteurs dont la carboxine sur les mitochondries de Botrytis cinerea isolées de mycélium. Du fait de l'apparition de phénomènes de résistance aux produits anti-Botrytis, la lutte contre la pourriture grise demeure un problème. La chaine respiratoire de $\mathrm{B}$ cinerea, dont on connaît peu de chose, pourrait constituer une cible intéressante pour découvrir des produits de remplacement. Cet article décrit une méthode simple pour préparer des mitochondries de B cinerea et précise leurs caractéristiques. Le NADH, le succinate et l' $\alpha$-cétoglutarate sont des substrats qui stimulent fortement la consommation d'oxygène. Les contrôles respiratoires sont élevés et prouvent que le transport des électrons est bien couplé à la phosphorylation oxydative. Les rapports ADP/O obtenus avec les 3 substrats sont compatibles avec les valeurs théoriques. L'addition de cytochrome $\mathrm{c}$ n'augmente pas notablement la consommation en oxygène provoquée par l'ascorbate : la qualité de la membrane externe des mitochondries est suffisante pour empêcher le cytochrome c de réagir sur la chaine respiratoire. Ces observations montrent que les mitochondries isolées présentent une bonne intégrité tant sur le plan structural que fonctionnel. Cette étude montre aussi qu'elles ne possèdent pas une voie alternative résistante à l'antimycine $A$ et au cyanure mais présentent une voie insensible à la roténone. Les effets et les niveaux d'activité de l'oligomycine, du carbonylcyanide mchlorophénylhydrazone (CCCP) et du carboxyatractyloside sur les mitochondries de B cinerea ont été similaires à ceux généralement observés avec les mitochondries végétales. A $10 \mu$ mol.t.t, la carboxine inhibe complètement l'oxydation du succinate par les mitochondries de B cinerea mais n'a aucun effet sur les oxydations du NADH et de l' $\alpha$-cétoglutarate. Ce niveau de toxicité est comparable à celui relevé par d'autres auteurs avec des champignons appartenant à la classe des Basidiomycètes.

inhibiteur de la respiration / voie résistante à la roténone / carboxine / voie alternative / B cinerea

* Correspondence and reprints

Abbreviations: EDTA: ethylenediaminetetraacetic acid; BSA: bovine serum albumin; RCR: respiratory control ratio; ADP/O ratio: micromoles adenosine diphosphate/microatoms oxygen utilized; TPP: thiamine pyrophosphate; TMPD: $N, N, N^{\prime}, N$-tetramethyl-pphenylenediamine; TTFA: thenoyltrifluoracetone; CCCP, carbonylcyanide $m$-chlorophenylhydrazone. 


\section{INTRODUCTION}

Botrytis cinerea, an economically important phytopathogenic fungus, causes grey mould in various plants. Due to the development of resistant strains (Leroux and Clerjeau, 1985), its practical control remains a problem especially in vineyards. Although the morphological and biochemical characteristics of $B$ cinerea have been studied extensively, little is know about its respiratory chain. However, the respiratory chain of $B$ cinerea could be an interesting target for alternative fungicides. So, this paper describes the preparation and the properties of $B$ cinerea mitochondria. Then, the effects of carboxin, an antifungal carboxamide used for control of several Basidiomycetes is studied on these organelles.

\section{METHODS}

\section{Growth}

The $B$ cinerea strain was a wild-type strain sensitive to dicarboximide, aromatic hydrocarbon and benzimidazole fungicides (Fritz et al, 1977; Leroux and Fritz, 1984). Conidia were obtained from 15-d cultures grown on potato-dextrose agar slopes in test tubes. Mycelial colonies were prepared by seeding $8.10^{5} \mathrm{co}-$ nidia $\mathrm{ml}^{-1}$ in the following media: $10 \mathrm{~g}$ glucose or $10 \mathrm{~g}$ starch; $2 \mathrm{~g} \mathrm{KH}_{2} \mathrm{PO}_{4} ; 1.5 \mathrm{~g} \mathrm{~K}_{2} \mathrm{HPO}_{4} ; 0.5 \mathrm{~g} \mathrm{Mg} \mathrm{SO}$, $7 \mathrm{H}_{2} \mathrm{O} ; 1 \mathrm{~g}\left(\mathrm{NH}_{4}\right)_{2} \mathrm{SO}_{4} ; 2 \mathrm{~g}$ yeast extract and deionized water made up to $1 \mathrm{I}, \mathrm{pH} 6.2$. Incubation took place at $23^{\circ} \mathrm{C}$ on a rotary shaker at $150 \mathrm{rpm}$ for $26 \mathrm{~h}$.

\section{Mitochondrial preparation}

The young hyphae were harvested by filtration, washed twice with refrigerated distilled water and finally with the isolation medium which consisted of 0.5 mol..$^{-1}$ sucrose, $5 \mathrm{mmol}^{-1}$ cysteine, $1 \mathrm{mmol}^{-1} \mathrm{I}^{-1}$ EDTA, $0.3 \%(w / v)$ BSA, 0.1 mol. I $^{-1}$ sodium phosphate buffer, $\mathrm{pH}$ 7.4. All subsequent operations were performed in the cold $\left(0-4{ }^{\circ} \mathrm{C}\right)$. The hyphae were suspended in a 3 -fold volume of isolation medium and disrupted for $3 \times 3 \mathrm{~s}$ with a Multi-Moulinette mixer (Moulinex, France). The suspension of disrupted hyphae was then filtered in $<3 s$ through 2 layers of non-woven cloth lining round the basket of an electric juice extractor (Moulinex, France). The mitochondria were collected from the filtrate by .differential centrifugation, as a fraction sedimenting between $6000 \mathrm{~g}$ for $15 \mathrm{~min}$ and $10000 \mathrm{~g}$ for $20 \mathrm{~min}$. The mitochondrial pellet was washed in $0.5 \mathrm{~mol}^{-\mathrm{I}^{-1}}$ sucrose, $1 \mathrm{mmol} . \mathrm{I}^{-1}$
EDTA, $0.3 \%(w / v)$ BSA, 0.1 mol..$^{-1}$ sodium phosphate buffer, $\mathrm{pH} 7.4$ and centrifuged again at $10000 \mathrm{~g}$ for $20 \mathrm{~min}$. The final mitochondrial suspension was carefully resuspended with a small brush in $250 \mu \mathrm{l}$ of washing medium and kept on ice until use. Protein was determined by the procedure of Hartree (1972).

\section{Measurement of oxygen uptake}

Oxygen consumption was measured polarographically at $25{ }^{\circ} \mathrm{C}$ with a Clark-type oxygen electrode (Yellow Spring Instrument, USA) fitted to the Oxygraph model KIC (Gilson, USA). The standard reaction medium contained $0.5 \mathrm{~mol}^{-1}$ sucrose, $10 \mathrm{mmol} . \mathrm{I}^{-1} \mathrm{KCl}, 5$ mmol. $.^{-1} \mathrm{Mg} \mathrm{Cl}_{2}, 1 \mathrm{mmol.I^{-1 }}$ EDTA, $0.1 \%$ (w/v) BSA, $10 \mathrm{mmol} . \mathrm{I}^{-1}$ sodium phosphate buffer, $\mathrm{pH}$ 7.2. The final volume, including the $50 \mu \mathrm{l}$ of mitochondrial suspension (0.2-0.4 $\mathrm{mg}$ protein), was $2 \mathrm{ml}$. Respiratory rates were calculated from a recorded trace taking into account that the maximal concentration of oxygen in air-saturated reaction medium was $207 \mu$ mol..$^{-1}$. This value was found with our mitochondrial fraction in limiting concentrations of NADH (Estabrook and Mackler, 1957). RCR and ADP/O ratios were calculated as described by Estabrook (1967). All substrates were solubilized in the reaction medium and when needed in spite of the buffer, the $\mathrm{pH}$ was adjusted to 7.2 with small volumes of $1 \mathrm{~N}$ or $6 \mathrm{~N} \mathrm{KOH}$. FInal concentrations of substrates were $10 \mathrm{mmol}^{-1} \alpha$-ketoglutarate (plus $0.2 \mathrm{mmol}^{-1} \mathrm{NAD}^{+}$and $0.3 \mathrm{mmol}^{-1} \mathrm{I}^{-1} \mathrm{TPP}$ ), $10 \mathrm{mmol}^{-1}$ succinate (plus $0.2 \mathrm{mmol} . \mathrm{I}^{-1}$ ATP, $1 \mathrm{~min}$ before succinate), $1 \mathrm{mmol} . \mathrm{I}^{-1} \mathrm{NADH}$. All of the inhibitors were dissolved in ethanol except $\mathrm{NaCN}$ which was dissolved in water. The ethanol volumes used in each experiment were without effect on mitochondrial respiration.

\section{RESULTS}

\section{Mitochondrial preparation}

The amount of mycelium and the ratio of mycelium/isolation medium were critical for cell disruption. Usually $30-40 \mathrm{~g}$ (wet weight) of mycelium with $100 \mathrm{ml}$ of isolation medium gave the best results with our mixer. The disruption time was also very critical for mitochondrial integrity. We obtained the better coupled mitochondria with a disruption time of $3 \times 3 \mathrm{~s}$ (a longer time provided more mitochondrial protein but mitochondria were not as well coupled). In the above conditions, mitochondrial protein yield was 1-2 mg. The media chosen to prepare mitochondria were as simple as possible but the presence of BSA and EDTA always proved essential, particularly in the respiration medium. 


\section{Respiratory properties}

When $B$ cinerea was grown in the glucose medium, only exogenous NADH and succinate gave a well coupled respiration. This was not the case for endogenous $\mathrm{NADH}$-linked substrates like $\alpha$ ketoglutarate. To obtain well coupled respiration, not only with exogenous $\mathrm{NADH}$ and succinate but also with $\alpha$-ketoglutarate, $B$ cinerea had to be grown in the starch medium. Table I summarizes the results obtained for oxygen consumption, respiratory control and ADP/O ratios of mycelial mitochondria from $B$ cinerea. RCR values showed that electron transport in $B$ cinerea mitochondria was well coupled to oxidative phosphorylation. Good phosphorylation efficiencies (ADP/O ratios) were obtained with all three substrates. ADP/O ratios suggested that 2 coupling sites were utilized with exogenous $\mathrm{NADH}$ and succinate while 3 coupling sites were used with $\alpha$-ketoglutarate.

\section{Inhibitors of electron transport and oxidative phosphorylation}

For all tested substrates, oxidation was completely inhibited by addition of $1 \mu \mathrm{mol} . .^{-1}$ antimycin $A$ or $0.5 \mathrm{mmol}^{-1} \mathrm{I}^{-1} \mathrm{NaCN}$ (fig 1a,b), which are both known to be effective inhibitors of electron transport, between cytochromes $b$ and $c 1$ and at cytochrome a a3, respectively. This indicated that $B$ cinerea mitochondria did not exhibit an alternative pathway resistant to antimycin $A$ and cyanide as observed in Aspergillus oryzae, Neurospora crassa or Ustilago maydis (Kawakita, 1971; Lambowitz and Slayman, 1971; Sherald and Sisler, 1972). As expected, the inhibitory effect of antimy$\operatorname{cin} A$ was shunted by the addition of $0.2 \mathrm{mmol}^{-I^{-1}}$ TMPD, an artificial electron mediator between cytochromes $b$ and $c 1$ (Lee et al, 1967).
Rotenone at $10 \mu \mathrm{mol} . \mathrm{I}^{-1}$ inhibited $\alpha$ ketoglutarate oxidation by up to $30 \%$ but failed to have any effect on NADH and succinate oxidation. At $20 \mu \mathrm{mol} . \mathrm{I}^{-1}$ and over, the inhibitory effect of rotenone on $\alpha$-ketoglutarate oxidation never exceeded $40 \%$. At the same time, the $A D P / O$ ratio decreased to a value indicating that only 2 coupling sites were still functioning (fig 1b). A complete inhibition was obtained with further addition of antimycin $A$. Such results suggest that $B$ cinerea mitochondria have a rotenone-insensitive respiratory route, like higher plant mitochondria (Douce, 1985).

We checked over the activity of TTFA and carboxin (5,6-dihydro-2-methyl-1,4-oxathiin-3carboxanilide), as specific inhibitors of succinate oxidation at the level of complex II (White et al, 1983). While it was necessary to use 2 mmol..$^{-1}$ TTFA to completely inhibit succinate oxidation, only $10 \mu \mathrm{mol} . \mathrm{I}^{-1}$ of carboxin were sufficient. 1 $\mu$ mol..$^{-1}$ carboxin inhibited succinate oxidation by up to $68 \%$ (not shown). This efficiency is similar to that reported by Ulrich and Mathre (1972) in $U$ maydis mitochondria.

At $15 \mu \mathrm{mol} . \mathrm{I}^{-1}$, oligomycin, an inhibitor of oxidative phosphorylation, added to state 3 (during which the oxidative phosphorylation occurs) decreased the oxidation of all substrates tested to a level close to the respiration normally observed during state 4 (during which to ATP is formed). As found with higher plant mitochondria (Ikuma and Bonner, 1967) this inhibition was released by $3 \mu \mathrm{mol} . \mathrm{I}^{-1}$ of a known uncoupler like CCCP and subsequent addition of ADP had no effect (fig 1a). Three $\mu$ mol. I $^{-1}$ CCCP added alone during state 4 strongly increased $(200 \%)$ oxygen consumption (not shown). In all cases a further addition of $1 \mu \mathrm{mol} . \mathrm{I}^{-1}$ antimycin A completely inhibited the oxygen consumption generated by CCCP (fig 1a).

Table I. Respiratory properties of mitochondria isolated from mycelia of $B$ cinerea.

\begin{tabular}{lccc} 
Substrates & $\begin{array}{c}\text { State } 3 \text { respiration rates } \\
\left(\mathrm{nmol} \mathrm{O2} \mathrm{min}^{-1}(\mathrm{mg} \text { protein })^{-1}\right)\end{array}$ & $\begin{array}{c}\text { Respiratory } \\
\text { control ratios (RCR) }\end{array}$ & $\begin{array}{l}\text { ADP/O } \\
\text { ratios }\end{array}$ \\
\hline $\mathrm{NADH}$ & $157 \pm 53$ & $3.6 \pm 0.3$ & $1.23 \pm 0.07$ \\
Succinate & $115 \pm 40$ & $2.7 \pm 0.8$ & $1.31 \pm 0.08$ \\
$\alpha$-Ketoglutarate & $55 \pm 16$ & $3.5 \pm 0.5$ & $2.21 \pm 0.14$
\end{tabular}

Note: The respiratory activities were measured polarographically at $25^{\circ} \mathrm{C}$ as described in Methods. The ADP concentration was $100 \mu \mathrm{mol}^{-\mathrm{I}^{-1}}$ and reactions were carried with 0.2 to $0.4 \mathrm{mg}$ mitochondrial protein. Mean values \pm SEs are given for 5 determinations. 

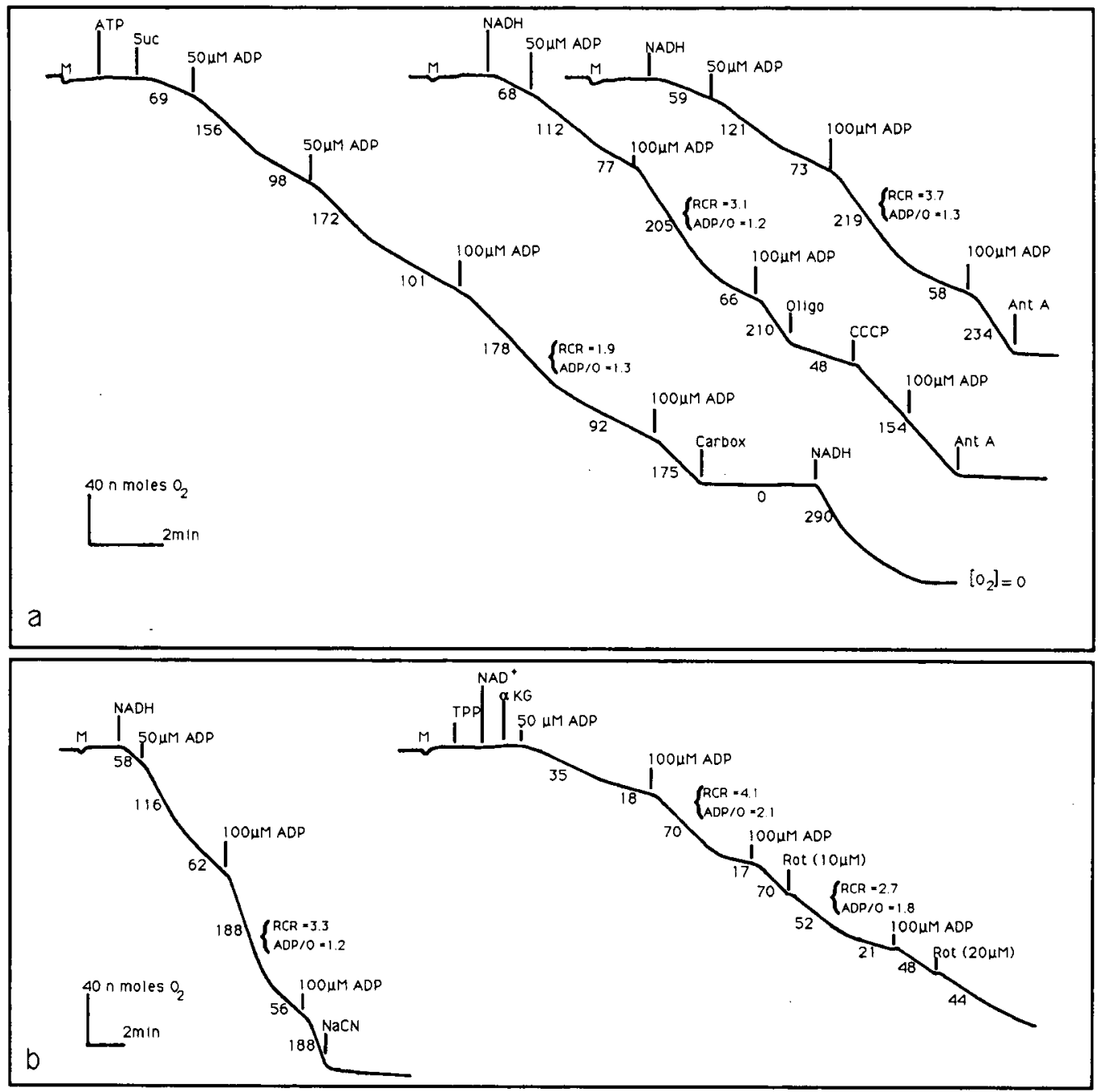

Fig 1. Oxidation of NADH, succinate (Suc) and $\alpha$-ketoglutarate $(\alpha K G)$ by mitochondria isolated from mycelia of $B$ cinerea. Concentrations of substrates were : a) antimycin A (Ant A), $1 \mu$ mol..$^{-1}$; carboxin (Carbox), $10 \mu \mathrm{mol}^{-\mathrm{I}^{-1}}$; CCCP, $3 \mu \mathrm{mol}^{-1^{-1}}$ and oligomycin (Oligo), $15 \mu \mathrm{mol} . \mathrm{I}^{-1}$; b) rotenone (Rot), 10 to $20 \mu \mathrm{mol} . \mathrm{I}^{-1}$ and $\mathrm{NaCN}, 0.5 \mathrm{mmol} . \mathrm{I}^{-1}$. The numbers beside each trace show the rate of oxygen uptake in $\mathrm{nmol} 02 \mathrm{~min}^{-1}\left(\mathrm{mg}\right.$ protein) ${ }^{-1}$; the reactions were carried out at $25^{\circ} \mathrm{C}$ with $0.2-0.4 \mathrm{mg}$ protein.

\section{DISCUSSION}

We have shown that it is necessary to grow $B$ cinerea in a medium containing starch (instead of glucose) to obtain well coupled mitochondria with all substrates tested. Except for the fact that in the starch medium $B$ cinerea was morphologically different and grew more slowly we have no satisfactory explanation for this phenomenon. However, for Schwitzguébel et al (1981) the growth conditions changed the density of mitochondria isolated from $N$ crassa and this should reflect changes in lipid and/or protein composition of mitochondria.

Our results showed that washed mitochondria isolated from $B$ cinerea mycelia, without purifica- tion procedure, rapidly oxidize $\alpha$-ketoglutarate, succinate and NADH with good respiratory control and ADP/O ratios, indicating that these organelles sustain a high level of structural and functional integrity. The addition of $30 \mu \mathrm{mol}^{-\mathrm{I}^{-1}}$ cytochrome $c$ did not greatly enhance the $\mathrm{O}_{2}$ consumption due to $8 \mathrm{mmol}^{-\mathrm{I}^{-1}}$ ascorbate (results not shown). This agrees with the good integrity of our washed mitochondria (Neuburger et al, 1982).

We have shown that $B$ cinerea mitochondria are devoid of the alternative pathway resistant to antimycin $A$ and cyanide. However, by growing $N$ cassa in the presence of antimycin A, cyanide or chloramphenicol, Lambowitz and Slayman (1971) induced the alternative pathway. With $B$ 
cinerea we did not attempt the same experiment, but we did not succeed in inducing the alternative pathway with sodium salicylate which has been described as calorigen in the genus Arum (Raskin et al, 1987).

With regard to the rotenone-insensitive respiratory route observed in $B$ cinerea mitochondria, we have shown that it was different from the alternative pathway because it was completely inhibited by antimycin $A$.

Carboxin and, more generally, carboxamides are specifically valuable systemic fungicides for control of Basidiomycetes (smuts and rusts of cereals as well as rots caused by Rhizoctonia solani). However, carboxin is know to be an inhibitor of complex II of the electron transport system in a variety of organisms, including sensitive fungi ( $U$ maydis), tolerant fungi (Fusarium oxysporum, Saccharomyces cerevisiae), higher plants (Phaseolus vulgaris) and animals (pig heart, rat liver) (Mathre, 1971; Ulrich and Mathre, 1972). Even though published data indicate that succinateubiquinone reductase activities from Basidiomycetes fungi, mammalian sources and bacterium (Micrococcus denitrificans) are more sensitive than those from higher plants and the yeast $S$ cerevisiae, the selectivity of carboxamides seems to be relative (Kuhn, 1984). Moreover, we have found that carboxin strongly inhibits succinate oxidation in $B$ cinerea mitochondria, which is in accordance with the in vitro toxicity of this compound, for several Deuteromycetes including Botrytis sp, reported by Edgington and Barron (1967). If the present carboxamides failed to control $B$ cinerea in the field, this is not due to a differential sensitivity of the target site or a lower accessibility of the fungal wall and plasmalemma to this site.

The reason for this is to be found among the obstacles encountered by systemic fungicides before reaching the fungus such as biological and non-biological conversion into non-fungitoxic substances. Chin et al (1969) reported that carboxin is oxidized to its inactive sulfoxide in water, soil and plants like wheat, barley and cotton. Maybe it could be possible to find particular structural analogs of carboxin which are effective in practice, among carboxamides.

With $B$ cinerea mitochondria we can easily test wether a product is an inhibitor of the oxidative phosphorylation or an uncoupler by using respectively CCCP or oligomycin. With mitochondria from potato tubers, Macherel et al (1986) reported another uncoupling test using carboxyatracty- loide, an inhibitor of adenine nucleotide transport. We had obtained the same results with $B$ cinerea mitochondria and $10 \mu \mathrm{mol} . \mathrm{I}^{-1}$ carboxyatractylosisde instead of $15 \mu \mathrm{mol} . \mathrm{I}^{-1}$ oligomycin (not shown).

If we except the alternative pathway, we have observed a respiratory chain similar to that encountered in the mitochondria of microorganisms (Lloyd, 1974) in $B$ cinerea mitochondria. The washed mitochondria described in the present paper will allow us to accurately study the mode of action of fungicides on the respiratory chain of $B$ cinerea.

\section{REFERENCES}

Chin WT, Stone GM, Smith AE (1969) Fate of carboxin in soil, plants and animals. Proc Br Insectic Fungic Conf 2, 322-327

Douce R (1985) Mitochondria in Higher Plants. Structure, Function and Biogenesis. Academic Press, New York, 103-112

Edgington LV, Barron GL (1967) Fungitoxic spectrum of oxathiin compounds. Phytopathology 57, 12561257

Estabrook RW (1967) Mitochondrial respiratory control and the polarographic measurement of ADP:0 ratios. In: Methods in Enzymology (Estabrook RW, Pullman ME, eds) Academic Press, New York, 4147

Estabrook RW, Mackler B (1957) Enzymatic and spectrophotometric studies of a reduced diphosphopyridine nucleotide oxidase preparation from heart muscle. J Biol Chem 229, 1091-1103

Fritz R, Leroux P, Gredt M (1977) Mécanisme de l'action fongitoxique de la promidione (26019 RP ou glycophène) de la vinchlozoline et du dicloran sur Botrytis cinerea Pers. Phytopathol Z90, 152-163

Hartree EF (1972) Determination of protein: a modification of the Lowry method that gives a linear photometric response. Anal Biochem 48, 422-427

Ikuma H, Bonner WD (1967) Properties of higher plant mitochondria. II. Effects of DNP, $m$-Cl-CCP, and oligomycin on respiration of mung bean mitochondria. Plant Physiol 42, 1400-1406

Kawakita M (1971) Studies on the respiratory system of Aspergillus oryzae. III. Properties of mitochondria from mycelia grown in the presence of antimycin A. J Biochem 69, 35-42

Kuhn PJ (1984) Mode of action of carboxamides. In: Mode of Action of Antifungal Agents (Trinci APJ, Ryley JF, eds) Cambridge University Press, Cambridge, 155-183

Lambowitz AM, Slayman CW (1971) Cyanideresistant respiration in Neurospora crassa. J Bacteriol 108, 1087-1096 
Lee CP, Sottocasa GL, Ernster L (1967) Use of artificial electron acceptors for abbreviated phosphorylating electron transport : flavin-cytochrome $c$. In: Methods in Enzymology (Estabrook RW, Pullman ME, eds) Academic Press, New York, 33-37

Leroux P, Fritz R (1984) Antifungal activity of dicarboximides and aromatic hydrocarbons and resistance to these fungicides. In: Mode of Action of Antifungal Agents (Trinci APJ, Ryley JF, eds) Cambridge University Press, Cambridge, 207-237

Leroux P, Clerjeau M (1985) Resistance of Botrytis cinerea Pers and Plasmopara viticola (Berk et Curt) Berl and de Toni to fungicides in French vineyards. Crop Protection 4, 137-160

Lloyd D (1974) The Mitochondria of Microorganisms. Academic Press, London

Macherel D, Tissut M, Nurit F, Ravanel P, Bergon M, Calmon JP (1986) Inhibitory action of an isopropyl carbanilate series on mitosis, respiration and photosynthesis. Physiol Veg 24, 97-107

Mathre DE (1971) Mode of action of oxathiin systemic fungicides. III. Effect on mitochondrial activities. Pestic Biochem Physiol 1, 216-224

Neuburger M, Journet EP, Bligny R, Carde JP, Douce $R$ (1982) Purification of plant mitochondria by iso- pycnic centrifugation in density gradients of Percoll. Arch Biochem Biophys 217, 312-323

Raskin I, Ehmann A, Melander WR, Meeuse BJD (1987) Salicylic acid: a natural inducer of heat production in Arum lilies. Science 237, 1601-1602

Schwitzguébel JP, Moller IM, Palmer JM (1981) Changes in density of mitochondria and glyoxysomes from Neurospora crassa: a re-evaluation utilizing silica sol gradient centrifugation. J Gen Microbiol 126, 289-295

Sherald JL, Sisler HD (1972) Selective inhibition of antimycin A-insensitive respiration in Ustilago maydis and Ceratocystis ulmi. Plant Cell Physiol 13, 10391052

Ulrich JT, Mathre DE (1972) Mode of action of oxathiin systemic fungicides. V. Effect on electron transport system of Ustilago maydis and Saccharomyces cerevisiae. J Bacteriol 110, 628-632

White GA, Thorn GD, Ackrell BAC, Kearney EB, Ramsey RR, Singer TP (1983) Site of action of carboxamides in mitochondrial complex. II. In: Pesticide Chemistry, Human Welfare and the Environment. Mode of Action, Metabolism and Toxicology (Miyamoto J, Kearney PC, eds) Pergamon Press, New York, 141-146 